\title{
The influence of atypical antipsychotic drugs on sexual function
}

\author{
This article was published in the following Dove Press journal: \\ Neuropsychiatric Disease and Treatment \\ 8 July 2015 \\ Number of times this article has been viewed
}

\section{Marek J Just}

Department of General and Endocrine Surgery, Piekary Medical Centre, Piekary Slaskie, Poland
Correspondence: MJ Just

Department of General and Endocrine Surgery, Piekary Medical Centre,

I I Szpitalna St, Piekary Slaskie 4I-940, Poland

Email marek.just@wp.pl

\begin{abstract}
Human sexuality is contingent upon many biological and psychological factors. Such factors include sexual drive (libido), physiological arousal (lubrication/erection), orgasm, and ejaculation, as well as maintaining normal menstrual cycle. The assessment of sexual dysfunction can be difficult due to the intimate nature of the problem and patients' unwillingness to discuss it. Also, the problem of dysfunction is often overlooked by doctors. Atypical antipsychotic treatment is a key component of mental disorders' treatment algorithms recommended by the National Institute of Health and Clinical Excellence, the American Psychiatric Association, and the British Society for Psychopharmacology. The relationship between atypical antipsychotic drugs and sexual dysfunction is mediated in part by antipsychotic blockade of pituitary dopamine $\mathrm{D}_{2}$ receptors increasing prolactin secretion, although direct correlations have not been established between raised prolactin levels and clinical symptoms. Variety of mechanisms are likely to contribute to antipsychotic-related sexual dysfunction, including hyperprolactinemia, sedation, and antagonism of a number of neurotransmitter receptors ( $\alpha$-adrenergic, dopaminergic, histaminic, and muscarinic). Maintaining normal sexual function in people treated for mental disorders can affect their quality of life, mood, self-esteem, attitude toward taking medication, and compliance during therapy.
\end{abstract}

Keywords: schizophrenia, galactorrhea, hyperprolactinemia, mood disorders, anorgasmia

\section{Introduction}

Sexual dysfunction is a common problem in people with mood disorders, ${ }^{1}$ schizophrenia, and other psychotic disorders, with reported prevalence rates of $30 \%-80 \%$ in women and $45 \%-80 \%$ in men. ${ }^{2-4}$ In clinical practice, sexual disorders are found as a complication in people treated with antipsychotics. The prevalence rate of sexual disorders in men treated with antipsychotics is estimated to be 54\% (Figure 1). Among them, 38\% have problems in achieving erection, $42 \%$ with maintaining erection, at least $19 \%$ have ejaculation disorders (reduced volume or no ejaculation), and 58\% have reduced orgasm intensity. Furthermore, in men, priapism, galactorrhea (3\%), and gynecomastia (6\%) may also be observed. Sexual disorders are found in about $30 \%$ of women treated with antipsychotics. According to the results obtained by different authors, reduced orgasm quality (33\%), reduced ability to reach orgasm (22\%), and pain during orgasm $(7 \%)$ were the most common problems in women treated with antipsychotics. However, hyperprolactinemia, galactorrhea $(5 \%-19 \%)$, and breast swelling (3\%) are more frequently found in women than in men. Furthermore, irregular (78\%) or complete suppression of menstrual cycles $(22 \%-50 \%)$ was observed in women. ${ }^{5}$ In people receiving psychiatric treatment, the possibility of other concurring factors should also be considered (chronic metabolic diseases and other medications) that can affect sexual function. Sexual dysfunction can also be related to thyroid disorders. ${ }^{6}$ The concurrence of thyroid disease in mentally ill 


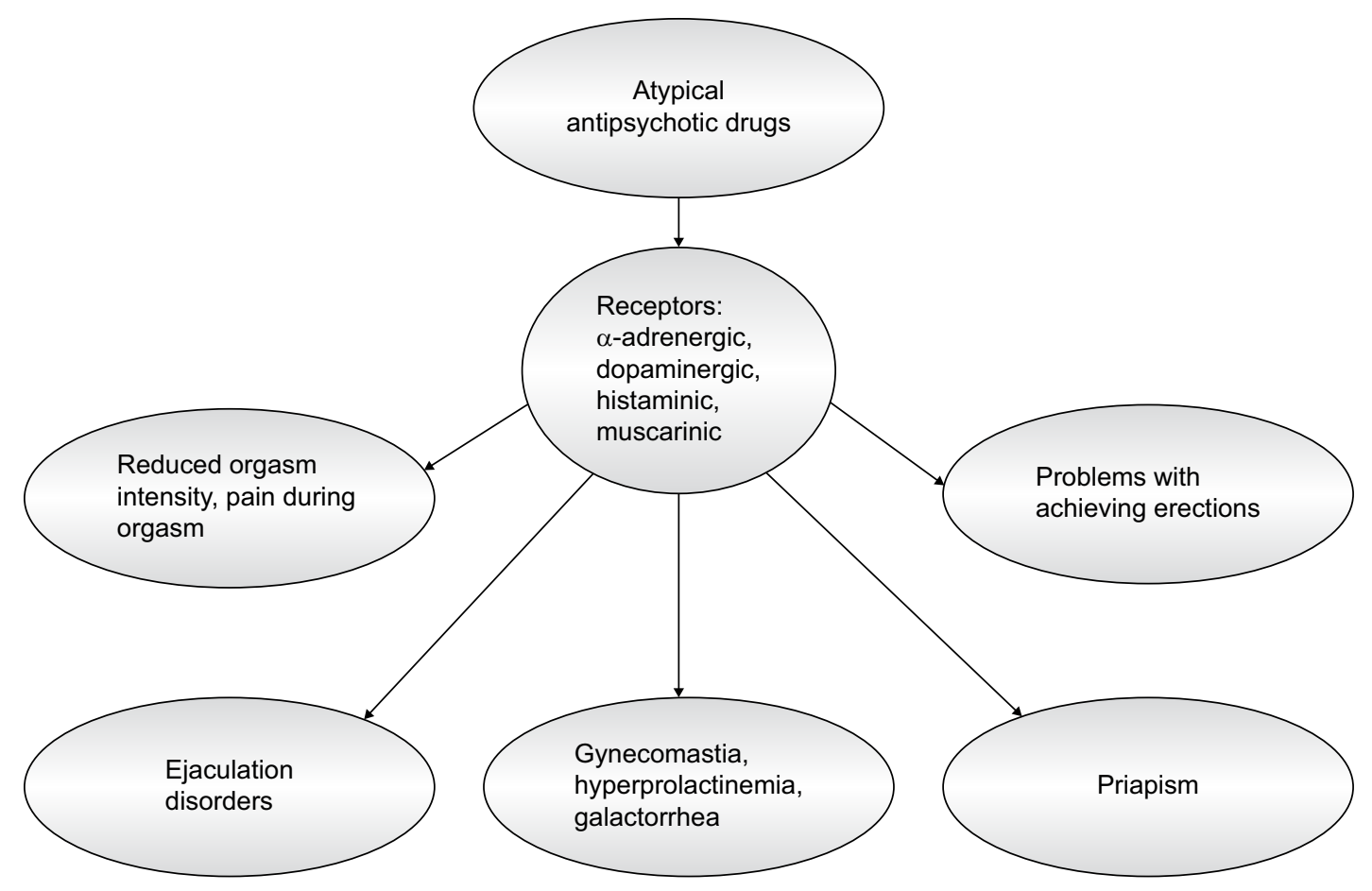

Figure I The involvement of atypical antipsychotic drugs in development of sexual dysfunctions.

patients may significantly delay the onset of pharmacological treatment, including treatment with antipsychotic drugs, and delay the use of slow transcranial magnetic stimulation ${ }^{7}$ and electroconvulsive therapy. ${ }^{8}$ Thus, a detailed medical history to confirm or exclude sexual disorders before commencing psychiatric treatment is extremely important. The sexual function of the patient should therefore be evaluated in the premorbid period, during the period from illness onset to treatment initiation, after treatment initiation, and also during exacerbation of mental disease and remission. ${ }^{9}$

Atypical antipsychotics (AAPs) are recommended for the treatment of schizophrenia and other psychotic disorders, including those resulting from organic diseases. These drugs have a more extensive influence on the range of schizophrenia symptoms (deficits, affective, and cognitive) than typical antipsychotic drugs. ${ }^{10}$ Moreover, AAPs rarely cause side effects, such as neuroleptic malignant syndrome, versus typical antipsychotic drugs. ${ }^{11,12}$ AAPs may be considered as atypical when characterized by Melzert's constant (their affinity for $5-\mathrm{HT}_{2 \mathrm{~A}}$ and dopamine $\mathrm{D}_{2}$ receptors $\left[\mathrm{D}_{2} \mathrm{R}\right]$ should exceed or be equal to 1.12). Another distinct feature of atypical drugs is the $\mathrm{D}_{2} \mathrm{R}$-blocking time, which is directly correlated to the dissociation constant $\left(K_{\mathrm{d}}\right)$ of the ligand-receptor complex. AAP drugs form a ligand-receptor complex with a shorter lifespan than typical antipsychotics. Furthermore, the values of their dissociation constant are lower than $K_{\mathrm{d}}$ for dopamine. ${ }^{13}$ AAPs are also used in the treatment of bipolar disorder due to their mood stabilizing properties. They also enhance the antidepressant influence of drugs that are used in the treatment of other affective diseases such as atypical depression, ${ }^{14}$ drug-resistant depression, ${ }^{15}$ and depression resulting from organic disease.

AAPs can affect sexual function in the following ways: (1) through their specific central effect of blocking dopaminergic receptors in the hypothalamus, contributing to hyperprolactinemia, galactorrhea, menstruation, or erection disorders and reduced libido; (2) through their peripheral effect of blocking $\alpha$-adrenergic receptors, responsible for dilation of the arteries in the penis; (3) through an unspecific central sedative effect leading to reduced sexual activity. ${ }^{15}$

\section{The influence of AAPs on the central nervous system}

The influence of AAPs on sexual function is related to the activation of neurotransmitters such as dopamine and serotonin in the central nervous system. This process involves the brain's dopaminergic and serotonergic structures.

\section{The influence of dopamine on sexual function}

The dopaminergic structures involved in sexual motivation include the nucleus accumbens, which is a part of the 
mesolimbic pathway and the medial preoptic region of the hypothalamus. Stimulation of dopaminergic receptors of the paraventricular nucleus in the hypothalamus is important for causing erection. The serotonergic system (hippocampus and amygdala) has an inhibiting influence on sexual motivation, orgasm, and ejaculation. However, stimulation of individual serotonergic receptors in the central nervous system can cause various effects. The serotonergic receptors $5-\mathrm{HT}_{2}$ and $5-\mathrm{HT}_{3}$ have an inhibiting influence on sexual activity, while the stimulation of $5-\mathrm{HT}_{1 \mathrm{~A}}$ receptors stimulates these functions. ${ }^{16,17}$

AAPs have an influence on the synthesis and circulation of dopamine, which has an impact on libido, erection, and ejaculation. Dopamine is the most important hypothalamic prolactin (PRL)-inhibiting factor. Blocking dopamine secretion leads to hyperprolactinemia, which can inhibit sexual function, particularly libido and erection, by increasing gamma-aminobutyric acid (GABA)-ergic activity and opioid levels. ${ }^{18}$ Dopamine has an inhibiting influence on PRL secretion mainly via two pathways: the tuberoinfundibular dopaminergic (TIDA) system and the tuberohypophysial pathway. The TIDA system, formed by an aggregation of dopaminergic neurons found in the arcuate nucleus of the hypothalamus, plays the most important role in PRL release in humans. These dopaminergic neurons release dopamine into the perivascular space of the median eminence. Subsequently, dopamine is transported to the anterior lobe of the pituitary gland. The second inhibitory dopamine pathway, the tuberohypophyseal pathway, projects to the intermediate and posterior lobes of the pituitary gland. Dopamine released into the blood reaches the lactotroph cells and binds to the $\mathrm{D}_{2} \mathrm{R}$ on the membrane of these cells. $\mathrm{D}_{2} \mathrm{R}$ stimulation inhibits the synthesis and release of PRL, as well as lactotroph proliferation. The TIDA network is partially regulated by autocrine-negative feedback of PRL. An increase in circulating PRL levels results in higher activity of TIDA neurons, whereas a decrease in circulating PRL levels reduces their activity. Thus, PRL regulates its own release by acting directly on the hypothalamic dopaminergic neurons. PRL probably regulates tyrosine hydroxylase activity, the ratelimiting enzyme in dopamine synthesis. A blockade of $\mathrm{D}_{2} \mathrm{R}$ counteracts the tonic inhibitory effect on PRL secretion. Therefore, the stronger the dopamine blockade, the higher the increase in PRL. ${ }^{19,20}$

\section{PRL influence on sexual function}

Antipsychotics have a $\mathrm{D}_{2}$-blocking effect and can therefore increase PRL secretion. The normal reference values of PRL in the blood are $10-20 \mathrm{ng} / \mathrm{mL}$ in men and $10-25 \mathrm{ng} / \mathrm{mL}$ in women. ${ }^{21}$ PRL secretion increases during sleep and is at its highest during the rapid eye movement stage sleep. PRL levels increase to $30 \mathrm{ng} / \mathrm{mL}$ between $4 \mathrm{am}$ and $6 \mathrm{am}$. Current research has revealed that galactorrhea, impotence, azoospermia, and lack of libido are observed when PRL levels are $>60 \mathrm{ng} / \mathrm{mL} .^{22}$ Hyperprolactinemia can also lead to reduced blood testosterone levels and can indirectly contribute to reduced sexual activity. ${ }^{18,20}$ According to the research, $80 \%$ of men with PRL blood levels $>50 \mathrm{ng} / \mathrm{mL}$ had reduced libido and suffered from impotence. ${ }^{18,20}$ AAPs as a group cause less hyperprolactinemia than conventional antipsychotics; yet, there is considerable variation among specific drugs. ${ }^{5}$ Of the AAPs, risperidone, amisulpiride, and zotepine have the strongest stimulating effect on PRL synthesis. Asmal et $\mathrm{al}^{23}$ showed in their study that PRL levels were increased at the beginning of treatment and were significantly higher in patients treated with risperidone. The average increase in PRL levels was higher in women than in men. However, Suzuki et $\mathrm{al}^{24}$ showed that the highest PRL levels (higher in the group of studied women vs men) were measured in the blood of patients treated with risperidone or olanzapine as monotherapy, versus patients taking aripiprazole, quetiapine, and perospirone combined. Furthermore, Jeong et $\mathrm{al}^{25}$ found that increased PRL levels during treatment with risperidone was accompanied by sexual dysfunction, especially problems with sexual arousal and penile erection, which were measured by using the Arizona Sexual Experience Scale. ${ }^{26}$ The symptoms of sexual dysfunction disappeared after risperidone withdrawal and the commencement of aripiprazole. The influence of risperidone on the synthesis of PRL and sexual function are combined with its strong affinity for the $\mathrm{D}_{2}$ receptors and its simultaneous effect on the $5-\mathrm{HT}_{2}$ receptors. Peuskens et $\mathrm{al}^{21}$ found that among men receiving risperidone at a dose of $1-16 \mathrm{mg} /$ day, $4.2 \%-17.7 \%$ had problems with erection and $3.6 \%-17.7 \%$ had a problem with ejaculation. The authors suggested that hyperprolactinemia could be the cause of these dysfunctions. Nevertheless, Jummani and Coffey ${ }^{27}$ observed mild hyperprolactinemia (11-21 ng/mL), premature ejaculation, and impotence in patients treated with risperidone at a dose of $3.5 \mathrm{mg} /$ day. Other AAPs such as clozapine and quetiapine do not display an influence on PRL secretion. ${ }^{23}$ However, Serretti and Chiesa ${ }^{28}$ showed that sexual dysfunction (desire, arousal, and orgasm dysfunction) occurred during treatment with quetiapine and aripiprazole, although PRL blood levels were within the normal range. These observations indicate that other factors such as chronic stress and metabolic diseases (hypertension and diabetes) can be responsible for sexual dysfunction. 
Olanzapine is another AAP that influences PRL levels and sexual function. ${ }^{29}$ This results in olanzapine binding with a wide range of dopaminergic $\left(\mathrm{D}_{1}, \mathrm{D}_{2}, \mathrm{D}_{3}, \mathrm{D}_{4}\right)$ and serotonergic $\left(5-\mathrm{HT}_{2 \mathrm{~A}}, 5-\mathrm{HT}_{3}, 5-\mathrm{HT}_{6}, 5-\mathrm{HT}_{2 \mathrm{C}}\right)$ receptors. According to many studies, olanzapine is characterized by having a lower and more selective affinity for dopaminergic receptors (mainly the mesolimbic pathway) than risperidone. Konarzewska et $\mathrm{al}^{30}$ in their own research found a temporary increase in PRL levels in patients treated with olanzapine. This increase was lower in the group of patients treated with olanzapine versus patients treated with risperidone. Similar results were obtained by Kim et $\mathrm{al}^{31}$ who observed a lower increase in PRL levels and sexual dysfunction following the change in treatment from risperidone to olanzapine. Baggaley ${ }^{32}$ noticed that risperidone showed a significantly higher influence on the development of sexual dysfunction versus olanzapine, quetiapine, and aripiprazole. There are also reports concerning sexual dysfunction and treatment with sertindole, in which orgasm without ejaculation was observed, which was associated with the peripheral $\alpha 1$-adrenergic antagonism of this drug, and also orgasm with ejaculation of reduced ejaculate volume. ${ }^{33}$ Sertindole is a second-generation antipsychotic drug with a high affinity for dopaminergic $\mathrm{D}_{2}$, serotonergic $5-\mathrm{HT}_{2 \mathrm{~A}}, 5-\mathrm{HT}_{2 \mathrm{C}}$, and $\alpha 1$-adrenergic receptors and a low affinity for other receptors. Muscatello et al, ${ }^{34}$ Lewis et al, ${ }^{35}$ and Jukić et $\mathrm{al}^{36}$ in their studies found that sertindole can cause sexual dysfunction independent of increased PRL levels, more commonly in men than in women.

\section{The influence of serotonin and noradrenaline on sexual function}

After dopamine, serotonin is the second most important neurotransmitter to influence sexual function. ${ }^{37}$ Serotonin mainly inhibits sexual function by stimulating postsynaptic $5-\mathrm{HT}_{2 \mathrm{~A}}$ and $5-\mathrm{HT}_{2 \mathrm{C}}$ receptors, while the stimulation of presynaptic $5-\mathrm{HT}_{1 \mathrm{~A}}$ autoreceptors increases sexual activity, reducing serotonin secretion from the nerve termini. Furthermore, reduction of the negative symptoms of schizophrenia is combined with the serotonergic system, particularly with antagonism of the $5-\mathrm{HT}_{2 \mathrm{~A}}$ and/or $5-\mathrm{HT}_{1 \mathrm{~A}}$ receptors. ${ }^{38,39}$ By blocking these receptors located on dopaminergic neurons, dopaminergic transmission in the mesocortical pathway is intensified, and as a result, cognitive (such as focusing attention and working memory) and executive functions are improved. On the other hand, an increase in transmission in the nigrostriatal pathway reduces the risk of neuroleptic malignant syndrome through disinhibition. Noradrenaline, another neurotransmitter, increases the ability for arousal through its influence on central receptors and inhibits erection by binding with peripheral $\alpha 1$ receptors. ${ }^{40}$

\section{The peripheral influence of AAP drugs}

The adrenergic system is one of the peripheral mechanisms that has an influence on penile erection. It is accompanied by the relative functional prevalence of the parasympathetic ( $\beta 2$-adrenergic activation) over the sympathetic ( $\alpha 1$-adrenergic inhibition) system, necessary to dilate penile arteries and for blood to flow into the cavernous bodies of the penis. ${ }^{41}$ One related sexual dysfunction is priapism. In this disorder, a prolonged, painful erection of the penis occurs, which is unrelated to sexual arousal or stimulation. Priapism can be caused by the blocking of $\alpha 1$-adrenergic receptors by AAP drugs. According to numerous studies, most of the AAP drugs, such as olanzapine, risperidone, and amisulpiride can cause priapism. It is worth noting that olanzapine can cause both reversible and irreversible priapism. ${ }^{42}$ The symptoms of reversible priapism after 10 days of olanzapine treatment at a dose of $10 \mathrm{mg}$ /day were observed by Doufik et al. ${ }^{43}$ Priapism symptoms disappeared when the treatment was changed from olanzapine to amisulpiride at a dose of $400 \mathrm{mg} /$ day. Furthermore, reversible priapism with olanzapine was also described by Penaskovic et al. ${ }^{44}$ This sexual dysfunction appeared after 7 days of olanzapine treatment at a dose of $15 \mathrm{mg} /$ day. However, Jagadheesan et $\mathrm{al}^{45}$ described irreversible priapism after treatment with olanzapine. The symptoms of priapism appeared on the sixth day of treatment with olanzapine at a dose of $5 \mathrm{mg} /$ day. Reversible priapism was also observed after treatment with other neuroleptics such as risperidone and ziprasidone. Ginory and Nguyen ${ }^{46}$ observed priapism after a month's therapy with risperidone at a dose of $6 \mathrm{mg}$ /day. Furthermore, Cruzado and Vallejos ${ }^{47}$ described priapism that developed during monotherapy with risperidone at a dose of $3 \mathrm{mg} /$ day, after 3 years of using the drug. Due to this adverse effect, risperidone was withdrawn and quetiapine at a dose of $450 \mathrm{mg} /$ day was prescribed for the patient and the side effect disappeared. Karamustafalioglu et $\mathrm{al}^{48}$ observed signs of priapism caused by ziprasidone at a dose of $40 \mathrm{mg} /$ day on the seventh day of treatment. The patient felt uncomfortable and stated that the condition had lasted for nearly 8 hours and was not associated with sexual stimulation or desire. Recurring priapism during treatment with ziprasidone at a total daily dose of $160 \mathrm{mg}$ (40 mg bid+ $80 \mathrm{mg}$ qhs) was described by Kaufman et $\mathrm{al}^{49}$ and with a dose of $140 \mathrm{mg}$ /day (ziprasidone with food, $80 \mathrm{mg}$ at bedtime 
and $60 \mathrm{mg}$ in the morning) was described by Denton et al. ${ }^{50}$ Ziprasidone can not only cause priapism but also cause spontaneous orgasm. AAP drugs may also cause very painful priapism in children. There is one case of a 12-year-old boy treated with risperidone at a dose of $4 \mathrm{mg} /$ day for schizophrenia, reported by Prabhuswamy et $\mathrm{al}^{51}$ and a second case of a 14-year-old boy treated with olanzapine at a dose of $5 \mathrm{mg} /$ day, reported by Husár and Zerhau. ${ }^{52}$

\section{The sedative influence of AAP drugs leading to reduced sexual activity}

AAP drugs can adversely influence sexual function due to their sedative effect. This process involves the blocking of dopaminergic and $5-\mathrm{HT}_{2 \mathrm{~A}}$ serotonergic receptors, antihistaminergic effects (blocking of $\mathrm{H}_{1}$ receptors), and an anticholinergic effect (blocking of muscarinic receptors). During optimalization of AAP treatment with regard to their antipsychotic influence, sedative symptoms leading to reduced sexual activity must be considered. When introducing AAP treatment, knowledge of the pharmacokinetics of the prescribed drug is important. It is recommended to administer the whole dose of the drug in the evening, yet sufficiently early enough so that the peak concentration of the drug in the blood decreases at the moment of falling asleep (medicine can be administered even 5-6 hours before sleep). ${ }^{53,54}$ By dosing olanzapine this way, the sedative effect and adverse influence on sexual function can be minimalized. During treatment with clozapine or quetiapine, these drugs should be administered in two daily doses due to their short half-life and in order to avoid sedative effects during the day. Also, the evening dose of the drug should be higher than that given in the morning. ${ }^{55,56}$ Aripirazole, sertindole, amisulpiride, and ziprasidone do not show sedative effects as they do not have any antihistaminergic and anticholinergic effects. Therefore, they do not have a negative effect on sexual function. ${ }^{57-59}$

\section{Conclusion}

Problems during therapy with AAP drugs include a lack of feedback from patients about the adverse effects caused by the drugs, particularly when they are combined with sexual dysfunction. Patients who do not tolerate these adverse effects may have problems with compliance during treatment. In conclusion, current knowledge about the mechanisms of sexual dysfunction caused by AAP drugs indicates the important role of dopaminergic blockade as a factor in reducing sexual drive as well as the ability to achieve erection and ejaculation, directly and as a result of hyperprolactinemia. Also, the blockade of alpha-1 and probably $\alpha 2$-adrenergic and muscarinic receptors is related to some disorders (impotence, priapism), although its final effects seem to depend on the location (ie, central, peripheral) of the target receptors to a larger extent, as well as on the overlapping, "modulating" receptor effects of a drug. The anti-serotonergic properties of AAP drugs can to some extent prevent sexual dysfunction.

\section{Acknowledgments}

The work was carried out at the Department of General Surgery, Municipal Hospital in Piekary Slaskie, Poland. Professional language editing has been performed by a native English speaker - Peter Kośmider-Jones. This research has received no specific grant from any funding agency in the public, commercial, or not-for-profit sectors.

\section{Author contribution}

MJJ contributed in the conception of the study, interpretation, preparation of manuscript, editing, revising, and recruitment.

\section{Disclosure}

The author reports no conflicts of interest in this work.

\section{References}

1. Grover S, Ghosh A, Sarkar S, Chakrabarti S, Avasthi A. Sexual dysfunction in clinically stable patients with bipolar disorder receiving lithium. J Clin Psychopharmacol. 2014;34(4):475-482.

2. Hamilton LD, Meston CM. Chronic stress and sexual function in women. $J$ Sex Med. 2013;10(10):2443-2454.

3. Agmo A. On the intricate relationship between sexual motivation and arousal. Horm Behav. 2011;59(5):681-688.

4. Boin AC, Nozoe KT, Polesel DN, Andersen ML, Tufik S. The potential role of sleep in sexual dysfunction in patients with schizophrenia. Schizophr Res. 2014;154(1-3):126-127.

5. Kopecek M, Bares M, Svarc J, Dockery C, Horacek J. Hyperprolactinemia after low dose of amisulpride. Neuro Endocrinol Lett. 2004;25(6) 419-422.

6. Oglodek E, Szota A, Araszkiewicz A. Electroconvulsive therapy in a patient with drug-resistant depression and thyroid hormone imbalance. Aust N Z J Psychiatry. 2014;48(1):96-97.

7. Oglodek E, Wiczkowski A, Sieron A, Bilska-Urban A, Moś D. The effect of extremely low-frequency magnetic fields on the morphology of thyroid gland cells in female rats. Pol J Environ Stud. 2008;17(5): $757-763$.

8. Kristensen D, Hageman I, Bauer J, Jørgensen MB, Correll CU. Antipsychotic polypharmacy in a treatment-refractory schizophrenia population receiving adjunctive treatment with electroconvulsive therapy. $J E C T$. 2013;29(4):271-276.

9. Millier A, Amri I, Boyer L, Auquier P, Toumi M. Utility decrements associated with side effects in schizophrenia. JMed Econ. 2014;17(12) 853-861.

10. Connolly A, Taylor D. Factors associated with non evidence-based prescribing of antipsychotics. Ther Adv Psychopharmacol. 2014;4(6) $247-256$.

11. Oglodek E, Szota A, Araszkiewicz A. Olanzapine-induced neuroleptic malignant syndrome after 10 years of treatment. Aust NZJ Psychiatry. 2013;47(10):972. 
12. Szota A, Ogłodek E, Araszkiewicz A. Fever development in neuroleptic malignant syndrome during treatment with olanzapine and clozapine. Pharmacol Rep. 2013;65(2):279-287.

13. Grundmann M, Kacirova I, Urinovska R. Therapeutic drug monitoring of atypical antipsychotic drugs. Acta Pharm. 2014;64(4):387-401.

14. Szota A, Oglodek E, Araszkiewicz A. A female patient with depression and conversion disorder following brain tumor surgery. Aust $N Z J$ Psychiatry. 2013;47(12):1213-1214.

15. Szota A, Ogłodek E, Araszkiewicz A. Bipolar disorder: mixed episodes concomitant with gambling addiction. Aust NZJ Psychiatry. 2013;48(6): 586-587.

16. Gründer G, Wetzel H, Schlösser R, et al. Neuroendocrine response to antipsychotics: effects of drug type and gender. Biol Psychiatry. 1999;45(1): 89-97.

17. Bevan JS. Interpreting prolactin levels: implications for the management of large pituitary lesions. Br J Neurosurg. 1991;5(1):3-6.

18. Freeman ME, Kanyicska B, Lerant A, Nagy G. Prolactin: structure, function, and regulation of secretion. Physiol Rev. 2000;80(4):1523-1631.

19. Haddad PM, Wieck A. Antipsychotic-induced hyperprolactinaemia: mechanisms, clinical features and management. Drugs. 2004;64(20): 2291-2314.

20. Kinon BJ, Gilmore JA, Liu H, Halbreich UM. Prevalence of hyperprolactinemia in schizophrenic patients treated with conventional antipsychotic medications or risperidone. Psychoneuroendocrinology. 2003; 28(supp1 2):55-68.

21. Peuskens J, Pani L, Detraux J, De Hert M. The effects of novel and newly approved antipsychotics on serum prolactin levels: a comprehensive review. CNS Drugs. 2014;28(5):421-453.

22. Weizmann A, Weizmann R, Hart J, Maoz B, Wijsenbeek H, Ben David M. The correlation of increased serum prolactin levels with decreased sexual desire and activity in elderly men. J Am Geriatr Soc. 1983;31(8): 485-488.

23. Asmal L, Flegar SJ, Wang J, Rummel-Kluge C, Komossa K, Leucht S. Quetiapine versus other atypical antipsychotics for schizophrenia. Cochrane Database Syst Rev. 2013;11:CD006625.

24. Suzuki Y, Sugai T, Fukui N, et al. Differences in plasma prolactin levels in patients with schizophrenia treated on monotherapy with five second-generation antipsychotics. Schizophr Res. 2013;145(1-3): $116-119$.

25. Jeong HG, Lee MS, Lee HY, Ko YH, Han C, Joe SH. Changes in sexual function and gonadal axis hormones after switching to aripiprazole in male schizophrenia patients: a prospective pilot study. Int Clin Psychopharmacol. 2012;27(4):177-183.

26. Buckley PF, Goldstein JM, Emsley RA. Efficacy and tolerability of quetiapine in poorly responsive, chronic schizophrenia. Schizophr Res. 2004; 66(2-3):143-150.

27. Jummani R, Coffey BJ. Hyperprolactinemia in an adolescent with psychotic disorder on risperidone. J Child Adolesc Psychopharmacol. 2009;19(6):791-794.

28. Serretti A, Chiesa A. A meta-analysis of sexual dysfunction in psychiatric patients taking antipsychotics. Int Clin Psychopharmacol. 2011;26(3): 130-140.

29. David SR, Taylor CC, Kinon BJ, Breier A. The effects of olanzapine, risperidone, and haloperidol on plasma prolactin levels in patients with schizophrenia. Clin Ther. 2000;22(9):1085-1096.

30. Konarzewska B, Wołczyński S, Szulc A, Galińska B, Popławska R, Waszkiewicz N. Effect of risperidone and olanzapine on reproductive hormones, psychopathology and sexual functioning in male patients with schizophrenia. Psychoneuroendocrinology. 2009;34(1): 129-139.

31. Kim KS, Pae CU, Chae JH, et al. Effects of olanzapine on prolactin levels of female patients with schizophrenia treated with risperidone. J Clin Psychiatry. 2002;63(5):408-413.

32. Baggaley M. Sexual dysfunction in schizophrenia: focus on recent evidence. Hum Psychopharmacol. 2008;23(3):201-209.

33. Martin-Du PR, Baumann P. Sexual dysfunctions induced by antidepressants and antipsychotics. Rev Med Suisse. 2008;4(150):758-762.
34. Muscatello MR, Bruno A, Pandolfo G, Micò U, Settineri S, Zoccali R. Emerging treatments in the management of schizophrenia - focus on sertindole. Drug Des Devel Ther. 2010;4:187-201.

35. Lewis R, Bagnall A, Leitner M. Sertindole for schizophrenia. Cochrane Database Syst Rev. 2000;(2):CD001715.

36. Jukić MK, Drmić S, Mimica N. Ejaculatory dysfunction in patient with schizophrenia on sertindole. Psychiatr Danub. 2010;22(1):128-131.

37. Crawford AM, Beasley CM Jr, Tollefson GD. The acute and long-term effect of olanzapine compared with placebo and haloperidol on serum prolactin concentrations. Schizophr Res. 1997;26(1):41-54.

38. Ogłodek EA, Szota A, Just MJ, Moś D, Araszkiewicz A. Comparison of chemokines (CCL-5 and SDF-1), chemokine receptors (CCR-5 and CXCR-4) and IL-6 levels in patients with different severities of depression. Pharmacol Rep. 2014;66(5):920-926.

39. Ogłodek EA, Szota AM, Just MJ, Moś DM, Araszkiewicz A. The MCP-1, CCL-5 and SDF-1 chemokines as pro-inflammatory markers in generalized anxiety disorder and personality disorders. Pharmacol Rep. 2015; 67(1):85-89.

40. Kleinberg DL, Davis JM, de Coster R, Van Baelen B, Brecher M. Prolactin levels and adverse events in patients treated with risperidone. J Clin Psychopharmacol. 1999;19(1):57-61.

41. Breier AF, Malhotra AK, Su TP, Pinals DA, Elman I, Adler CM. Clozapine and risperidone in chronic schizophrenia: effects on symptoms, parkinsonian side effects, and neuroendocrine response. Am J Psychiatry. 1999; 156(2):294-298.

42. Pérez-Iglesias R, Mata I, Martínez-García O, et al. Long-term effect of haloperidol, olanzapine, and risperidone on plasma prolactin levels in patients with first-episode psychosis. J Clin Psychopharmacol. 2012; 32(6):804-808.

43. Doufik J, Otheman Y, Khalili L, Ghanmi J, Ouanass A. Antipsychoticinduced priapism and management challenges: a case report. Encephale. 2014;40(6):518-521.

44. Penaskovic KM, Haq F, Raza S. Priapism during treatment with olanzapine, quetiapine, and risperidone in a patient with schizophrenia: a case report. Prim Care Companion J Clin Psychiatry. 2010;12(5). PCC.09100939.

45. Jagadheesan K, Thakur A, Akhtar S. Irreversible priapism during olanzapine and lithium therapy. Aust N Z J Psychiatry. 2004;38(5):381.

46. Ginory A, Nguyen M. A case of priapism with risperidone. Case Rep Psychiatry. 2014;2014:241573.

47. Cruzado L, Vallejos CE. Priapism associated with risperidone use: report of one case. Rev Med Chil. 2012;140(11):1445-1448.

48. Karamustafalioglu N, Kalelioglu T, Tanriover O, Gungor F, Genc A. A case report of priapism caused by ziprasidon. Psychiatry Investig. 2003; 10(4):425-427.

49. Kaufman KR, Stern L, Mohebati A, Olsavsky A, Hwang J. Ziprasidoneinduced priapism requiring surgical treatment. Eur Psychiatry. 2006; 21(1):48-50.

50. Denton K, Kolli V, Sharma A. Ziprasidone-induced ischemic priapism requiring surgical intervention: a case report. Prim Care Companion CNS Disord. 2013;15(1). PCC.12101443.

51. Prabhuswamy M, Srinath S, Girimaji S, Seshadri S. Risperidoneinduced priapism in a 12-year-old boy with schizophrenia. $J$ Child Adolesc Psychopharmacol. 2007;17(4):539-540.

52. Husár M, Zerhau P. Priapism in childhood-case report of 14-year-old boy. Rozhl Chir. 2006;85(7):329-330.

53. Brichart N, Delavierre D, Peneau M, Ibrahim H, Mallek A. Priapism associated with antipsychotic medications: a series of four patients. Prog Urol. 2008;18(10):669-673.

54. Reeves RR, Kimble R. Prolonged erections associated with ziprasidone treatment: a case report. J Clin Psychiatry. 2003;64(1):97-98.

55. Mitchell JE, Popkin MK. Antipsychotic drug therapy and sexual dysfunction in men. Am J Psychiatry. 1982;139(5):633-637.

56. Songer DA, Barclay JC. Olanzapine-induced priapism. Am J Psychiatry. 2001;158(12):2087-2088.

57. Shah SK. A comparative study of sexual dysfunction in schizophrenia patients taking aripiprazole versus risperidone. Kathmandu Univ Med J. 2013;11(42):121-125. 
58. Andersohn F, Schmedt N, Weinmann S, Willich SN, Garbe E. Priapism associated with antipsychotics: role of alpha1 adrenoceptor affinity. J Clin Psychopharmacol. 2010;30(1):68-71.
59. Ogłodek E, Szota A, Just M, Moś D, Araszkiewicz A. The role of the neuroendocrine and immune systems in the pathogenesis of depression. Pharmacol Rep. 2014;66(5):776-781.

\section{Publish your work in this journal}

Neuropsychiatric Disease and Treatment is an international, peerreviewed journal of clinical therapeutics and pharmacology focusing on concise rapid reporting of clinical or pre-clinical studies on a range of neuropsychiatric and neurological disorders. This journal is indexed on PubMed Central, the 'PsycINFO' database and CAS, and is the official journal of The International Neuropsychiatric Association (INA). The manuscript management system is completely online and includes a very quick and fair peer-review system, which is all easy to use. Visit http://www.dovepress.com/testimonials.php to read real quotes from published authors.

\footnotetext{
Submit your manuscript here: http://www.dovepress.com/neuropsychiatric-disease-and-treatment-journal
} 